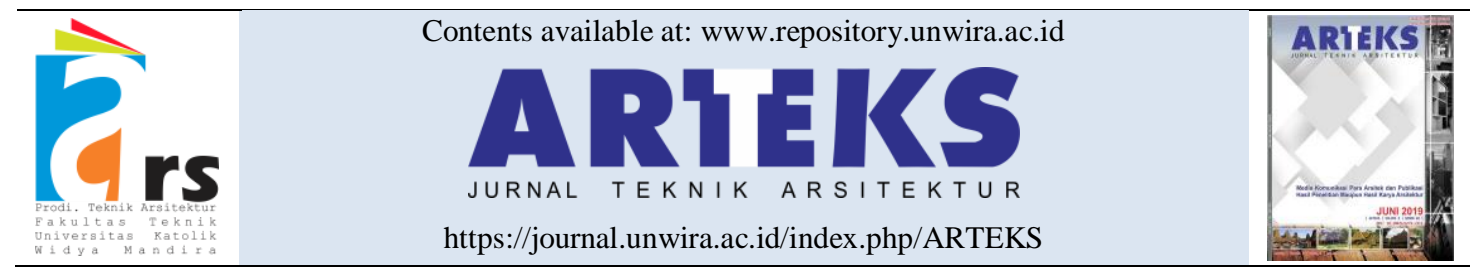

Research paper

doi: $10.30822 /$ arteks.v5i2.380

\title{
Analisis kondisi lingkungan, bangunan dan tempat rekreasi lansia pada panti jompo \\ Studi kasus: Sasana Tresna Werdha Karya Bhakti Ria Pembangunan dan Panti Werda Wisma Mulia
}

\author{
Santoni $^{1 *}$, Fransisca Yongsie ${ }^{2}$, Evian Devi $^{3}$ \\ ${ }^{1,2}$ Fakultas Teknik, Podomoro University \\ Central Park Mall $3^{\text {rd }}$ Floor - Unit 112, Jl. Let. Jend. S. Parman Kav. 28 \\ Jakarta Barat, 11470, Indonesia \\ ${ }^{3}$ Fakultas Teknik, Universitas Katolik Parahyangan, Bandung, Indonesia \\ Jl. Ciumbuleuit no. 94, Bandung, Indonesia
}

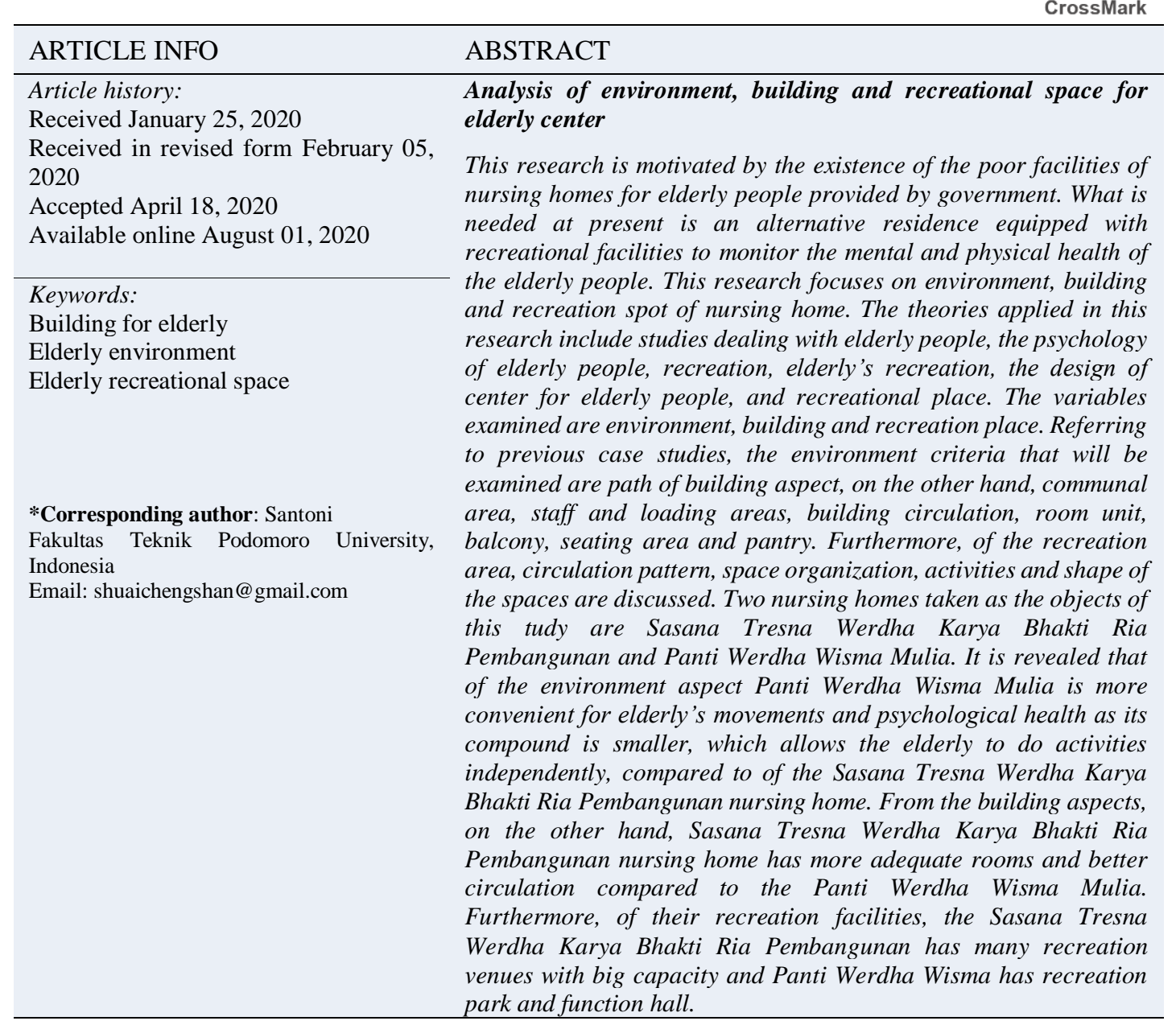

Copyright (C2020 Santoni, Francisca Yongsie, Evian Devi. This is an open access article distributed the Creative Commons Attribution-NonCommercial-ShareAlike 4.0 International License 


\section{Pendahuluan}

Menurut Dinas Kependudukan Amerika Serikat (1999), jumlah populasi lansia di dunia yang berusia 60 tahun ke atas diproyeksikan akan menjadi 2 miliar pada tahun 2050, pada saat itu jumlah populasi lansia akan melebihi jumlah populasi anak (0-14 tahun) (W. Setiawan et al. 2014). Peningkatan Usia Harapan Hidup (UHH) pun terus terjadi di Indonesia (Harismi 2019). Dalam periode 20 tahun mendatang, Indonesia diperkirakan dapat menekan angka kelahiran total dan angka kematian bayi serta meningkatkan proporsi penduduk lanjut usia atau lansia (Badan Perencanaan Pembangunan Nasional 2005).

Indonesia menjadi negara dengan jumlah lansia keempat terbanyak di dunia, setelah Cina, India, dan Amerika Serikat. Sampai pada tahun 2018 ini, jumlah penduduk lansia telah mencapai 24,7 juta jiwa (9,3 persen dari jumlah penduduk) (Suryowati 2018). Menurut Maryam (2014) diperkirakan pada tahun 2020, jumlah lansia di Indonesia mencapai 28,8 juta jiwa (11,34 persen dari jumlah penduduk) (W. Setiawan et al. 2014). Bahkan data Biro Sensus Amerika Serikat memperkirakan Indonesia akan mengalami peningkatan penduduk lansia terbesar di seluruh dunia pada tahun 1990-2025, yaitu sebesar 41.4 persen.

Menurut Junaidi (2007), peningkatan penduduk lansia pada dasarnya merupakan dampak positif dari pembangunan (Junaidi 2007). Secara tidak langsung pembangunan ini berdampak negatif melalui perubahan nilai-nilai pada keluarga dalam merawat lansia yang berpengaruh terhadap kesejahteraan lansia (Murdiyanto and Gutomo 2017). Hal ini menyebabkan berkurangnya peran dan status keluarga terhadap lansia. Perubahan nilai-nilai keluarga tampak dalam meningkatnya jumlah Panti Jompo sebagai alternatif tempat untuk menitipkan lansia di seluruh Indonesia (dari 186 panti pada tahun 2002 menjadi 278 panti pada tahun 2009, sedangkan di database Departemen Sosial tercatat 444 Panti di seluruh Indonesia) (Triwanti, Ishartono, and Gutama 2014).

Dampak negatif yang ditimbulkan dari menitipkan lansia ke panti jompo adalah lansia yang tinggal di panti merasa tidak sebebas di rumah sehingga mengalami tekanan psikis seperti perasaan tersisih, terbuang, dah terisolir (Devi 2016). Lansia yang tidak dapat menerima kenyataan harus berada di panti akan berpengaruh pada psikisnya, hal ini menyebabkan lansia suka melamun, murung, memberontak, dan berperilaku aneh (Sitindaon 2009).

Cowgill dan Holmes (1972) mengemukakan bahwa tanggung jawab terhadap pemeliharaan orang tua atau lansia berubah dari keluarga menjadi pemerintah (Cowgill and Holmes 1972). Wadah yang disediakan pemerintah bagi lansia sebagian besar adalah panti jompo yang memberi kesan lansia tidak dapat melakukan aktivitas lebih karena kurangnya fasilitas yang disediakan dan sangat mempengaruhi psikologis lansia sehingga banyak dari lansia yang merasa "terbuang" (Sajangbati, Franklin, and Rompas 2015).

Peraturan Pemerintah (PP) nomor 43 Tahun 2014 menyebutkan dalam upaya peningkatan kesejahteraan sosial bagi lansia tercantum bahwa lansia mendapat pelayanan fasilitas, sarana, dan prasarana umum. Pelayanan fasilitas, sarana, dan prasarana umum salah satunya terdiri dari penyediaan fasilitas rekreasi dan olahraga khusus lansia (Pemerintah Pusat 2004). Fasilitas tersebut berupa penyediaan tempat duduk khusus, alat bantu lansia, pemanfaatan taman untuk olahraga, penyelenggaraan wisata lansia, dan penyediaan tempat kebugaran olahraga khusus lansia.

Jika melihat pertumbuhan penduduk lansia yang ada serta kebutuhan-kebutuhan hidup para lansia, saat ini diperlukan adanya sarana alternatif hunian kedua bagi lansia yang memberikan fasilitas rekreasi, kesehatan mental, dan fisik para lansia dan pelayanan umum layaknya rumah sendiri (Martiani and Setioko 2012). Lansia membutuhkan tempat tinggal dan fasilitas untuk dapat mewadahi aktivitasnya sehari-hari (Putri, Fitriana, and Ningrum 2015). Akan lebih baik jika lansia dapat bersosialisasi dan berkegiatan bersama dengan lansia seusianya (Kuntjorowati 2017). Dengan menciptakan kegiatan-kegiatan yang cocok, berkualitas, dan sesuai dengan usianya untuk mengisi keseharian dapat berdampak positif dalam peningkatan produktivitas pada diri lansia ( $\mathrm{P}$ and Wibowo 2014).

Di Indonesia sendiri belum terdapat elderly care center atau panti jompo yang dimanfaatkan sebagai tempat rekreasi. Pada contoh Walumba Elders Centre telah menerapkan fasilitas rekreasi dan dikunjungi oleh anak-anak dan orang tua yang dapat memunculkan rasa kekeluargaan dan meningkatkan kualitas hidup lansia.

Menurut Mubarak dan Iqbal (2016), seseorang yang telah memasuki masa lanjut usia akan mengalami beberapa permasalahan, salah satunya 
adalah perubahan perilaku (D. Setiawan 2016). Perubahan perilaku yang sering dijumpai diantaranya: daya ingat menurun, penurunan merawat diri, sensivitas emosional yang dapat menjadi sumber masalah, dan lainnya. Melalui pendekatan arsitektur perilaku, diharapkan dapat menjawab permasalahan tersebut dan memahami kebutuhan dasar para lansia (Laurens 2004).

Berdasarkan uraian di atas, dapat ditarik sebuah permasalahan yaitu perubahan nilai-nilai pada keluarga yang mengharuskan lansia tinggal di panti jompo yang fasilitasnya kurang sehingga memberi kesan "terbuang" dan terjadinya perubahan perilaku pada lansia. Melihat dari permasalahan tersebut, maka dilakukan penelitian lebih lanjut mengenai desain dari elderly care center yang ditinjau dari kondisi lingkungan, bangunan dan tempat rekreasi yang sesuai untuk lansia, juga dapat mengakomodasi aktivitas dan kebutuhan para lansia agar para lansia dapat merasa betah atau nayaman, dan mendukung setiap kebutuhan lansia, serta meningkatkan kualitas hidup dan produktivitas lansia (Sugiharto 2017).

Rumusan masalah pada penelitian ini akan berfokus pada kondisi lingkungan dan bangunan pada panti jompo dan kegiatan dan tempat rekreasi untuk lansia. Tujuan penelitian ini untuk mengetahui kriteria yang dapat menjawab kebutuhan lansia pada lingkungan dan juga bangunan panti jompo sehingga dapat mendukung tempat dan kegiatan rekreasi untuk lansia. Manfaat penelitian ini adalah dengan adanya rujukan mengenai kebutuhan atau spesifikasi lingkungan dan bangunan panti jompo diharapkan dapat digunakan pada perancangan sehingga lingkungan, bangunan dan tempat rekreasi panti jompo dapat menjadi lebih baik lagi.

\section{Metode penelitian}

Metode penelitian yang digunakan dalam penelitian ini adalah metode kualitatif dengan melakukan observasi lapangan pada objek penelitian. Observasi dilakukan terhadap lansia di dua buah studi kasus, yaitu: Sasana Tresna Werdha Karya Bhakti Ria Pembangunan dan Panti Werdha Wisma Mulia. Kedua Bangunan ini dipilih karena keduanya memiliki besaran bangunan yang jauh berbeda, Panti Werdha Wisma Mulia kurang lebih $1000 \mathrm{~m}^{2}$, sedangkan
Sasana Tresna Werdha Karya Bhakti Ria Pembangunan memiliki luas bangunan sekitar $6000 \mathrm{~m}^{2}$. Kriteria penilaian dalam observasi didapatkan dari poin yang telah disebutkan melalui teori perancangan senior living dan tipologi bangunan rekreasi aktif komersil (Michael, Green, and Farquhar 2006). Kedua hasil akan sangat berbeda, namun hasilnya akan digunakan dalam pemilihan isu rekreasi pada panti jompo, karena rekreasi merupakan hal yang abstrak sehingga, belum tentu bangunan yang lebih besar akan mendukung rekreasi secara keseluruhan, sebab panti jompo merupakan bangunan yang fokus kepada lingkup personal seorang lansia.

Studi kasus yang pertama merupakan Panti Jompo yang terletak di Jakarta Barat tepatnya di Grogol, yaitu di Jalan Hadiah no. 14-16, Kelurahan Jelambar, Kecamatan Grogol Petamburan, Jakarta Barat (Lihat gambar 1). Panti ini bertingkat 2 lantai dan dulunya merupakan Panti Werdha khusus wanita yang kemudian berkembang menjadi panti jompo campuran. Panti Jompo ini didirikan pada tahun 1961 oleh Yayasan Bina Daya Wanita dibawah binaan KOWANI (Kongres Wanita Indonesia) dengan ketua Yayasan Bina Daya Wanita. Penghuni Panti Jompo ini mayoritas beretnis Tionghoa dengan penghuni berjumlah \pm 74 orang lansia. Penghuni panti ini memiliki agama hampir $60 \%$ beragama Kristen (60 orang) dan Katolik (6 orang), hampir 35\% beragama Buddha (27 orang), dan $5 \%$ beragama Islam (3 orang). 


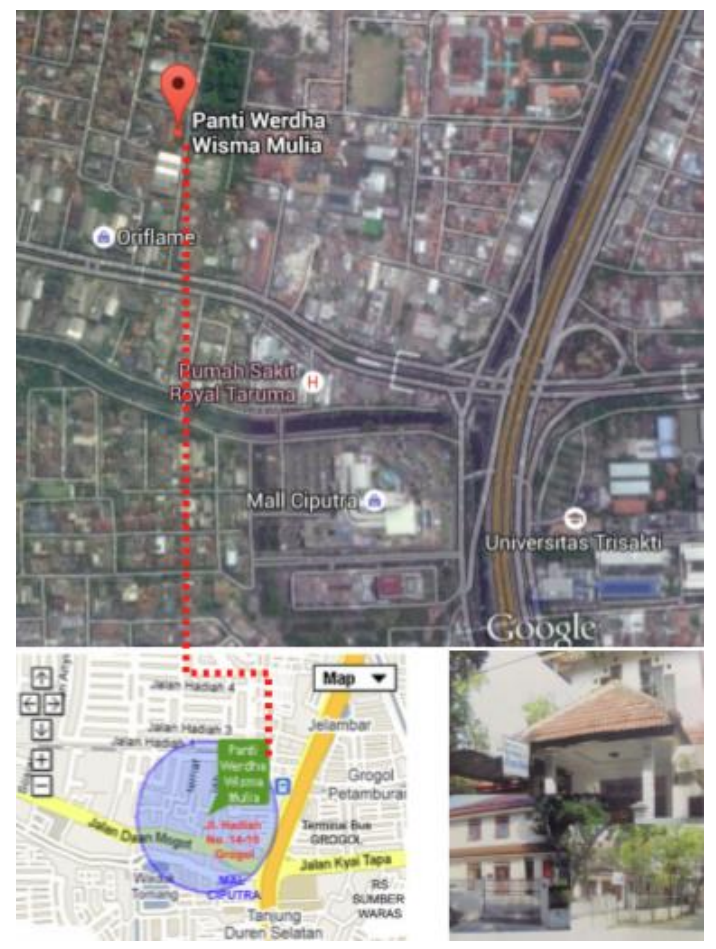

Gambar 1. Peta studi kasus: Panti Werdha Wisma Mulia

Studi kasus yang kedua merupakan Sasana Tresna Werdha Karya Bhakti Ria Pembangunan yang beralamat di Jalan Pusdika, RT. 8, RW. 7, Cibubur, Kec. Ciracas, Kota Jakarta Timur, Daerah Khusus Ibukota Jakarta 13720 (Lihat gambar 2). Sasana Tresna Werdha Karya Bhakti Ria Pembangunan terdiri dari 3 lantai serta memiliki jumlah penghuni yaitu 65 lansia (40 oma dan 25 opa), serta 35 lansia dari luar panti (daycare, setiap 3 hari dalam satu minggu). Beberapa syarat yang harus dipenuhi lansia yang ingin masuk ke Sasana Tresna Werdha Karya Bhakti Ria Pembangunan yaitu harus kemauan sendiri, sehat, mandiri, tidak memiliki penyakit menular, belum pikun, dan memiliki penanggung jawab minimal 3 orang. Perawatan yang didapatkan lansia yaitu perawatan kesehatan (disediakan poliklinik, check up, dan bangsal untuk lansia yang sedang sakit), pangan (makanan dimasak di dapur dan diantar menuju kamar masing-masing), papan (tempat tinggal lansia yaitu unit kamar di Sasana Tresna Werdha Karya Bhakti Ria Pembangunan), dan akses menuju tempat tertentu (mall, kolam renang, pasar, dan lainnya).

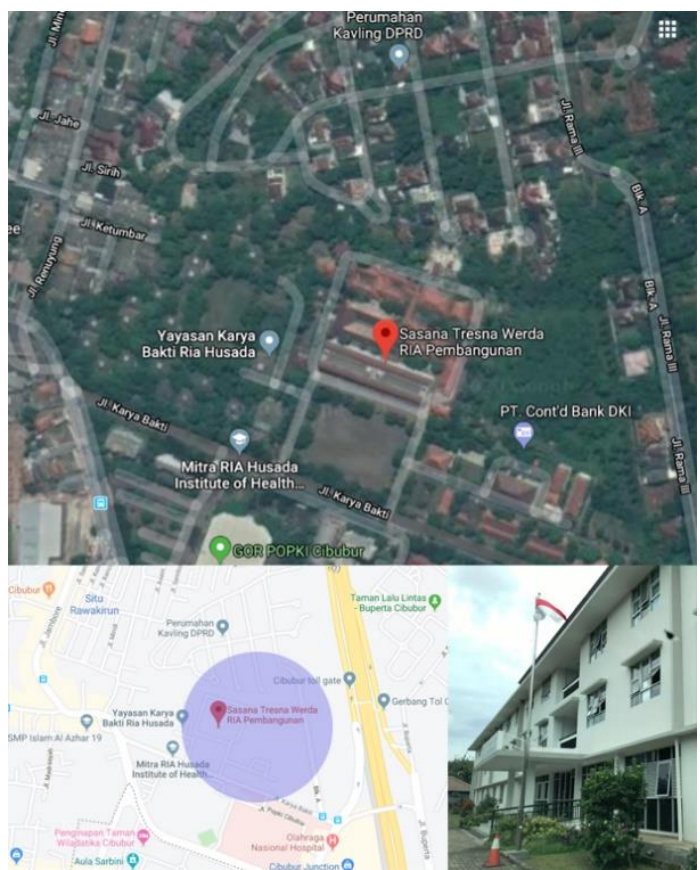

Gambar 2. Peta studi kasus: Sasana Tresna Werdha Karya Bhakti Ria Pembangunan

Berdasarkan teori perancangan hunian senior living menurut Sugiharto (Sugiharto 2017) dan perancangan tempat rekreasi menurut Linda, maka kriteria yang akan digunakan dalam meneliti kedua studi kasus tersebut adalah sebagai berikut (Lihat tabel 1):

Tabel 1. Penjabaran kriteria teori perancangan hunian senior living

\begin{tabular}{lll}
\hline No & Topik & Kriteria \\
\hline 1 & Lingkungan & $\begin{array}{l}\text { Jalur masuk tapak dan } \\
\text { bangunan }\end{array}$ \\
& & Area kedatangan \\
\hline & & Taman rekreasi pasif dan aktif \\
& & Area bercocok tanam \\
\hline Sirkulasi pedestrian \\
\hline 2 & Bangunan & Area komunal \\
\hline & & Area servis dan loading \\
\hline & & Area staff pengelola \\
\hline & & Sirkulasi Bangunan \\
\hline & & Ruang kamar duduk dan pantry \\
\hline & & Balkon dan unit kamar \\
\hline 3 & Tempat Rekreasi & Pemilihan tema \\
\hline & & Pola sirkulasi \\
\hline & & Pengolahan ruang \\
\hline & & Kegiatan \\
\hline & & Bentuk ruang \\
\hline & & Penyediaan fasilitas kegiatan \\
\hline
\end{tabular}




\section{Temuan dan pembahasan}

\section{Perancangan elderly care center}

Menurut Sugiharto (2017), perancangan hunian senior living terbagi menjadi lingkungan dan bangunan (Sugiharto 2017).

Lingkungan

Pada aspek lingkungan terdiri dari: jalur masuk tapak, jalur masuk bangunan, area kedatangan, entrance, taman rekreasi aktif, taman rekreasi pasif, area bercocok tanam dan area pedestrian. Uraian mengenai aspek-aspek lingkungan sebagai berikut: (1) Jalur masuk tapak. Gerbang masuk harus mudah di identifikasi; Bangunan masih berada di dalam jarak penglihatan dari arah jalan pada tapak; Jalan masuk yang banyak membantu tapak yang luas; Kemudahan akses untuk langsung menuju fasilitas kesehatan dan fasilitas perbelanjaan di sekitar lokasi tapak. (2) Jalur masuk bangunan. Perencanaan tatanan layout memudahkan bangunan untuk dikenal dan di identifikasi (Siwalankerto 2016); Tidak mencampurkan jalur kendaraan searah dengan jalur kendaraan dua arah; Kemudahan untuk keluar dan masuk kendaraan didalam tapak bangunan. Jarak dekat dan nyaman menuju akses masuk ke bangunan. (3) Area kedatangan. Posisi utama pada area kedatangan adalah untuk akses pengawasan dan area pelayanan didalam menyambut pendatang baru; Memiliki kemudahan akses jalan pedestrian menuju bangunan lain pada tapak; Area duduk terlindung dari terik matahari dan hujan namun tetap memiliki akses melihat pemandangan luar; Area duduk harus menyediakan akses keluar dan masuk bangunan sehingga, dapat melihat keramaian jalur yang akan ditempuh penghuni. (4) Entrance unit bangunan individual. Kelangsungan akses menuju jalan penghubung dari area parkir menuju pintu masuk bangunan; Pintu masuk bangunan memiliki pembedaan pada setiap unit bangunan agar memudahkan untuk diidentifikasi. (5) Taman rekreasi aktif. Didekatkan dengan aktivitas utama seperti balkon outdoor pada ruang komunal; Dapat diletakan berjauhan dengan bangunan untuk zonasi yang lebih tenang dan santai. (6) Taman rekreasi pasif. Didekatkan pada bukaan bangunan untuk memberi akses pemandangan bagi penghuni dari dalam bangunan; Berada jauh untuk eksplorasi dan retreat. (7) Area becocok tanam. Berada dekat dengan bangunan dan unit kamar penghuni pada zonasi yang berbeda; Tidak mendominasi pemandangan bangunan dan aktivitas luar. (8) Sirkulasi pedestrian. Akses keluar masuk bangunan yang mudah; Sirkulasi melewati aktivitas publik untuk memberi kesempatan bersosialisasi; Terdapat hierarki dari rute utama pada komunitas yang besar sehingga membutuhkan sirkulasi yang lebar, hingga menuju unit kamar pada jalur lebih kecil; Jalur sirkulasi harus memberikan kedekatan akses untuk area toilet dan peristirahatan; Tambahan papan petunjuk jalan sangat membantu lansia didalam menentukan arah tujuan kegiatan yang dituju.

Bangunan

Pada aspek bangunan, elemen terbagi menjadi area komunal, area servis dan loading, area staff pengelola, sirkulasi bangunan, taman rekreasi pasif, unit kamar, ruang duduk dan pantry dan balkon unit kamar. Penjelasan dari elemenelemen di atas adalah sebagai berikut: (1) Area komunal. Kedekatan akses menuju fasilitas lain; Penghubung seluruh fasilitas dan kegiatan; Memiliki hierarki dari ruang publik dan privat; Ruang komunal terlalu banyak akan membingungkan; Tidak memberi kontras ruang dari gelap dan terang karena mengganggu pengelihatan; Kemudahan dan kedekatan untuk mengakses toilet dan area peristirahatan. (2) Area servis dan loading. Tidak mengganggu aktivitas lansia untuk mengakses fasilitas bangunan; Tidak mendominasi pemandangan; Servis dari kebutuhan pendukung penghuni berdekatan dengan unit kamar. (3) Area staff pengelola. Tidak mendominasi ruang namun tidak juga terisolasi dari keseluruhan bangunan; Memiliki akses area servis ke unit hunian. (4) Sirkulasi bangunan. Kenyamanan pergantian suasana ruang; Membentuk pola yang mudah diidentifikasi; Memiliki hierarki dari publik ke privat untuk memberi penghuni rasa aman dan kontrol; Akses menuju unit hunian tidaklah harus melewati ruang fasilitas aktivitas komunal; Merancang runtutan perjalanan yang memiliki skema suasana ruang berbeda sehingga nyaman untuk dilalui; Tangga cukup lebar untuk beristirahat dengan maksimal 10 anak tangga. (5) Taman rekreasi pasif. Menjaga ruang terbuka dengan memberi taman kering sebagai area peristirahatan; Memberi transisi ruang melewati taman pasif sebelum melakukan aktivitas outdoor; Diletakan di tengah ruang aktivitas untuk memaksimalkan daya guna pemandangan; Sirkulasi jalan didalam bangunan melewati taman kering yang memiliki area duduk merupakan 
pergantian suasana yang baik. (6) Unit kamar. Memiliki teras depan untuk memberi personalisasi ruang; Jendela menyediakan pemandangan dan penyinaran matahari tidak langsung; Memiliki balkon dengan pemandangan taman; Sirkulasi ruang dalam dan bukaan pintu cukup leluasa untuk pengguna kursi roda. (7) Ruang duduk dan pantry. Sirkulasi ruang leluasa untuk kursi roda; Ruang duduk dapat melihat pemandangan; Ruang duduk dapat dipersonalisasi. (8) Balkon unit kamar. Tetap terlindung dari paparan terik matahari dan hempasan hujan; Cukup luas untuk peletakan kursi dan meja untuk bersantai melihat pemandangan.

\section{Panti Werdha Wisma Mulia}

\section{Lingkungan}

Hasil observasi terhadap Panti Werdha Wisma Mulia dalam aspek lingkungan yaitu: Jalur masuk tapak dan bangunan pada Panti Werdha Wisma Mulia hanya terdapat satu akses masuk dan satu akses keluar di bagian yang bersamaan. Bangunan ini mudah dijangkau oleh lansia karena jarak dari depan jalan ke bagian teras bangunan hanya berkisar 6 meter. Jalur pedestrian tersedia di bagian sisi luar bangunan menuju ke ruang serbaguna di sebelah kanan. Parkiran mobil hanya bisa berkisar 3-4 mobil. Bangunan mudah terlihat karena dekat dengan jalan utama. Area kedatangan pada bangunan ini terlihat jelas dari akses masuk bagian depan memudahkan lansia untuk langsung berjalan dari pintu depan menuju ke dalam bangunan (Lihat gambar 3 dan 4).

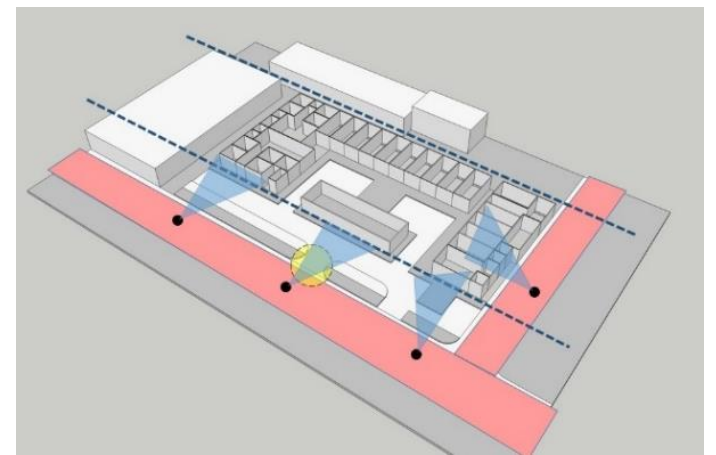

Gambar 3. Analisis jalur masuk tapak dan bangunan pada Panti Werdha Wisma Mulia

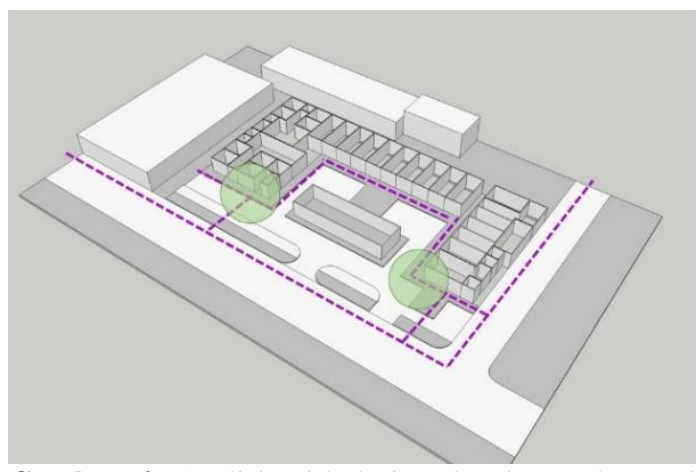

Gambar 4. Analisis sirkulasi pedestrian pada Panti Werdha Wisma Mulia

Sepanjang lingkungan letak Panti Werdha Wisma Mulia terdapat ruang terbuka persis di seberang jalan. Namun itu merupakan lahan kosong dan dipagari, memang tidak bisa dinikmati secara langsung namun masih bisa dilihat dari bagian teras karena tidak terlalu jauh.

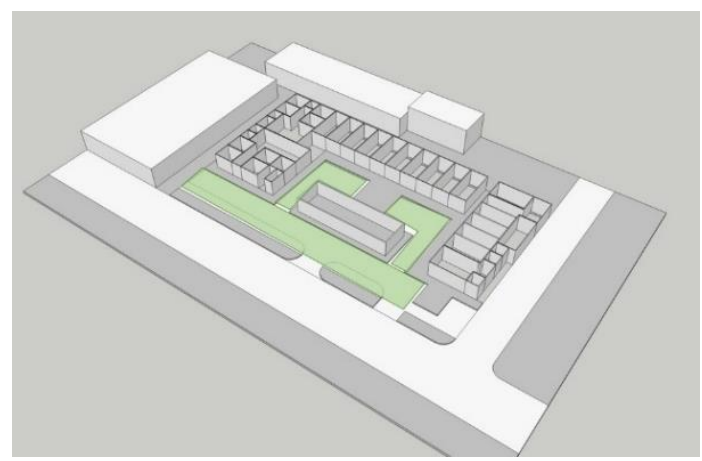

Gambar 5. Analisis taman rekreasi pasif dan aktif pada Panti Werdha Wisma Mulia

Panti Werdha Wisma Mulia sendiri tidak memiliki taman secara jelas, hanya berupa ruang terbuka di bagian tengah (ditunjukkan oleh warna hijau pada gambar 5). Ruang tersebut biasa digunakan untuk bertemu, berkumpul dan melakukan senam pagi. Terkadang ruang ini juga digunakan untuk berjemur di pagi hari seperti ditunjukan oleh gambar 6 . 


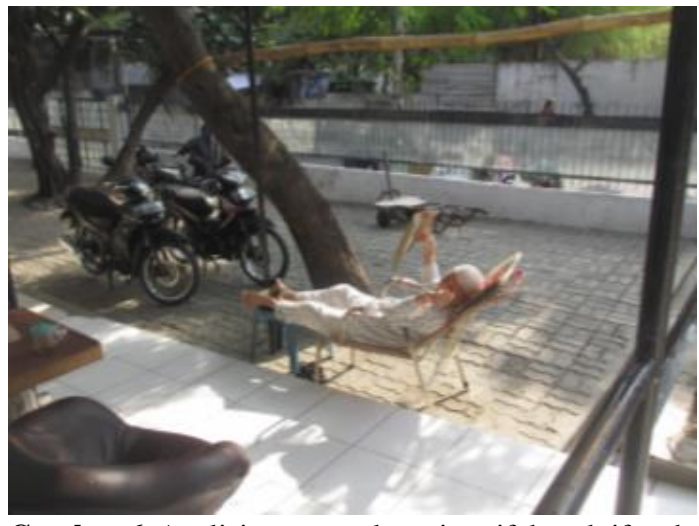

Gambar 6. Analisis taman rekreasi pasif dan aktif pada Panti Werdha Wisma Mulia

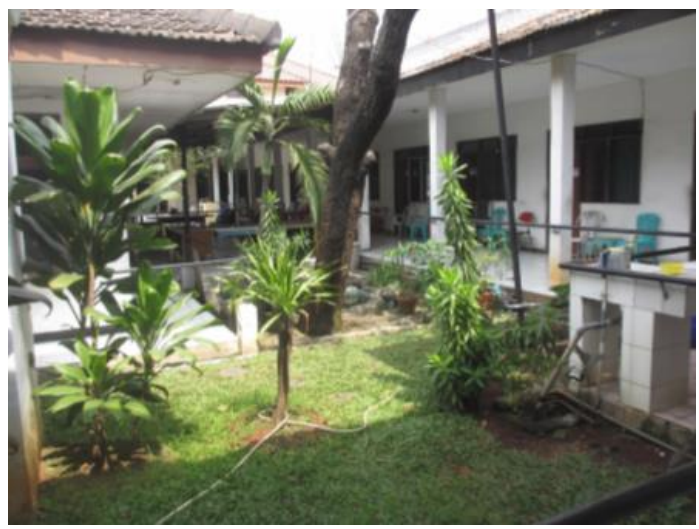

Gambar 7. Analisis taman rekreasi pasif dan aktif pada Panti Werdha Wisma Mulia

Bangunan Panti Werdha Wisma Mulia tidak kontras dengan bangunan yang ada di sekitarnya. Jenis atap pada bangunan ini juga tampak sama. Namun adanya tanda pengenal nama dan jarak bangunan yang tidak jauh dari jalan utama membuat bangunan ini dapat dikenali dengan baik (Lihat gambar 8).

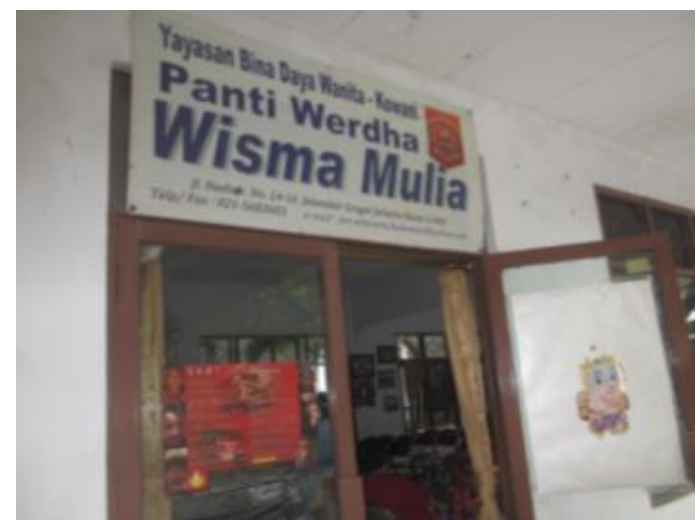

Gambar 8. Analisis taman rekreasi pasif dan aktif pada Panti Werdha Wisma Mulia

\section{Bangunan}

Bangunan Panti Werdha Wisma Mulia ini terdiri dari enam zoning. Nomor 1 menunjukan Ruang Serbaguna yang terletak tepat menghadap ke jalan. Terdapat taman di sisi kiri dan kanan (nomor 2) terbelah dengan ruang bagian tengah bangunan untuk bersoisalisasi (nomor 6). Bangunan ini dikelilingi oleh kamar setinggi dua lantai di bagian kiri dan kanan dan kamar yang berada dibagian tengah hanya setinggi satu lantai (nomor 3). Nomor 4 menunjukan kantor pengurus tepat berada pada muka kedua jalan dan ditambah dengan musholla (nomor 5) (Lihat gambar 9).

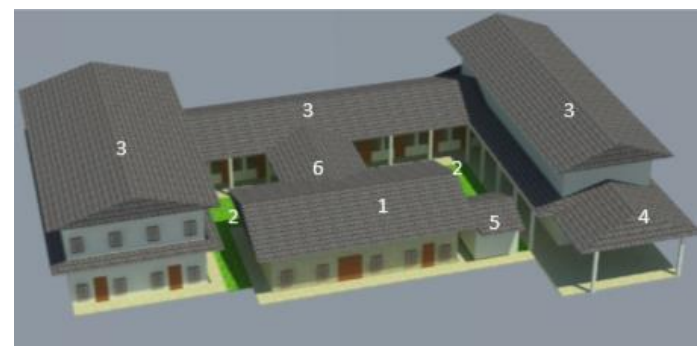

Gambar 8. Bangunan Panti Werdha Wisma Mulia

Tidak ada perbedaan sirkulasi publik dan juga privat secara jelas. Sirkulasi menuju kamar dihubungkan dengan adanya terasa sepanjang bangunan dan menghadap ke jalan utama. Koridor yang menghubungkan antar kamar langsung berhubungan dengan ruang terbuka di bagian tengah bangunan untuk beraktivitas.

Sirkulasi menuju toilet sangat dekat, di setiap kamar memiliki toilet da nada toilet di bagian ruang tengah yang berkisar hanya 5-10meter dari setiap kamar. Pola sirkulasi pada bangunan Panti Werdha Wisma Mulia tidak memiliki pola yang dinamis karena hanya berbentuk pola $U$ yang memanjang dan mengarah ke bentuk kotak (Lihat 
gambar 10). Pintu yang digunakan pada bangunan ini adalah pintu kayu.

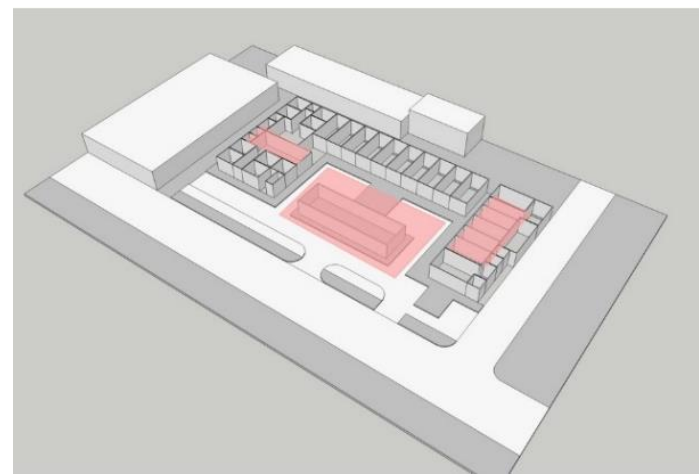

Gambar 9. Analisis fasilitas bangunan Panti Werdha Wisma Mulia

Fasilitas rekreasi pada bangunan Panti Werdha Wisma Mulia hanya terdapat pada dua area yaitu: ruang serba guna dan ruang kecil yang menghubungkan antar kamar di bagian kiri bangunan. Ruang serbaguna merupakan ruang yang paling sering digunakan untuk beraktivitas bagi lansia. Ruang tersebut dapat menampung kurang lebih 30-36 orang. Beberapa kegiatan bersama keluarga sering dilakukan di ruangan ini.

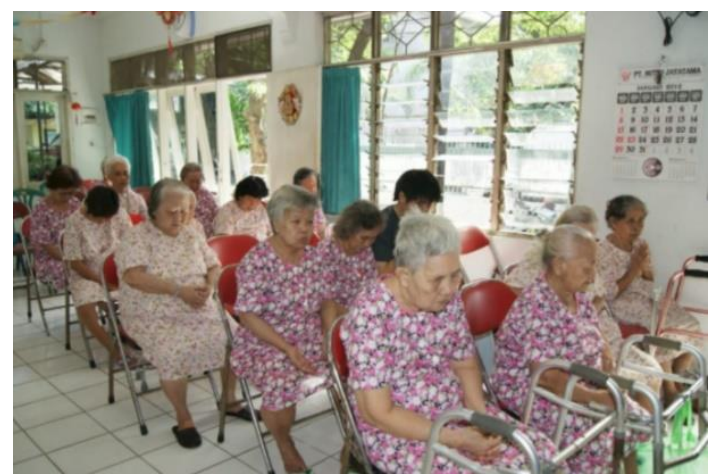

Gambar 10. Kegiatan di ruang serbaguna Panti Werdha Wisma Mulia

Unit kamar pada bangunan Panti Werdha Wisma Mulia menghadap kedua arah. Pintu bagian depan menghadap ke ruang tengah dan pintu di dalam kamar di sisi lain menghadap ke balkon bagian belakang. Balkon ini berfungsi jika lansia ingin mempunyai ruang yang lebih privat dibandingkan ruang tengah di dalam bangunan (Lihat gambar 12).

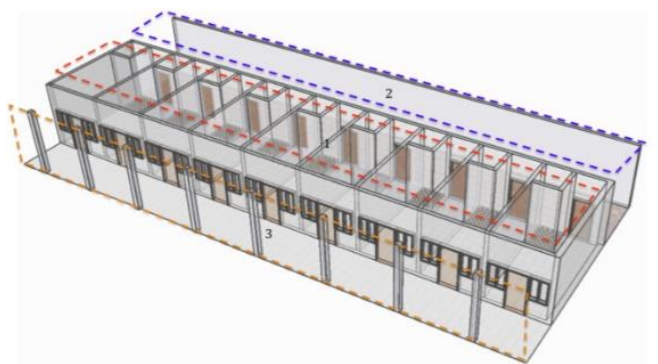

Gambar 12. Tipe unit kamar pada Panti Werdha Wisma Mulia

Tempat rekreasi

Pemilihan tema pada kegiatan rekreasi pada Panti Werdha Wisma Mulia ini memang tidak dijadwalkan setiap harinya. Namun, ruang-ruang terbuka dan juga koridor yang menghubungkan antar bangunan digunakan sebagai tempat dimana para lansia dapat beraktivitas. Pengolahan ruang membuat para lansia dapat saling berinteraksi satu dengan lainnya di bagian tengah. Bentuk massa yang mengelilingi ruang tengah menjadikan ruang tengah sebagai pusat tempat untuk berekreasi (Lihat gambar 13).

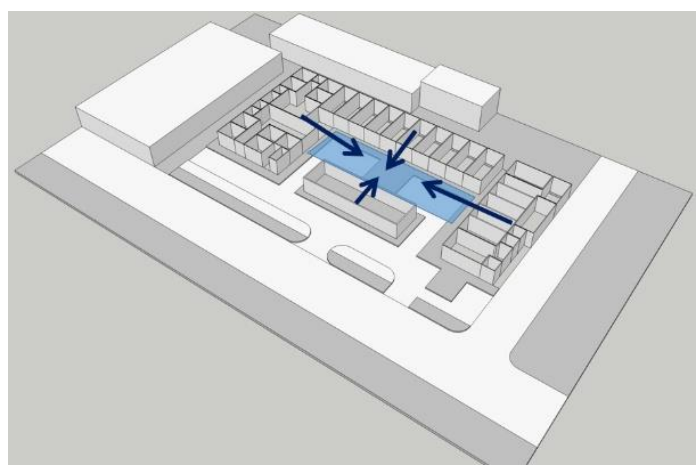

Gambar 11. Analisis pengolahan ruang pada Panti Werdha Wisma Mulia

Kegiatan yang dilakukan oleh lansia juga melibatkan pengunjung atau keluarga yang sedang mampir di panti werdha. Kegiatan yang dilakukan biasanya hanya setengah hari melihat lansia mempunyai jadwal untuk tidur siang, jadi kegiatan dilakukan pagi ke siang atau siang ke sore. Kegiatan tersebut merupakan kegiatan yang ringan seperti dapat dilihat pada gambar 14 ruang serbaguna digunakan untuk kegiatan indoor untuk berinteraksi satu dengan lainnya. Fasilitas yang digunakan juga tidak terlalu komplit seperti balon, kain dan permainan tradisional lainnya. 


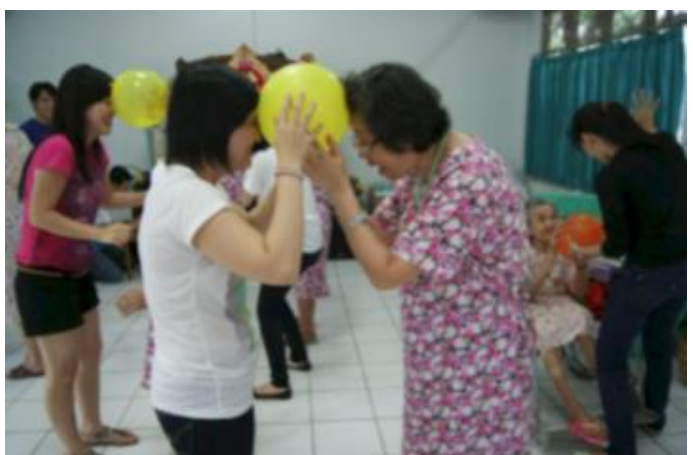

Gambar 14. Tema kegiatan rekreasi pada Panti Werdha Wisma Mulia

\section{Sasana Tresna Werdha Karya Bhakti Ria Pembangunan \\ Lingkungan}

Secara sirkulasi kendaraan, hanya terdapat satu akses masuk dan satu akses keluar (Lihat gambar 15). Bangunan tidak mudah dijangkau lansia karena jarak dari dropoff menuju ke luar yang cukup jauh $(130 \mathrm{~m})$, tidak tersedianya jalur pedestrian, dan tidak tersedianya parkir difable (total terdapat 30 parkir mobil). Bangunan tidak mudah terlihat dari jalan utama karena tampak kecil, lokasi bangunan jauh dari jalan utama).

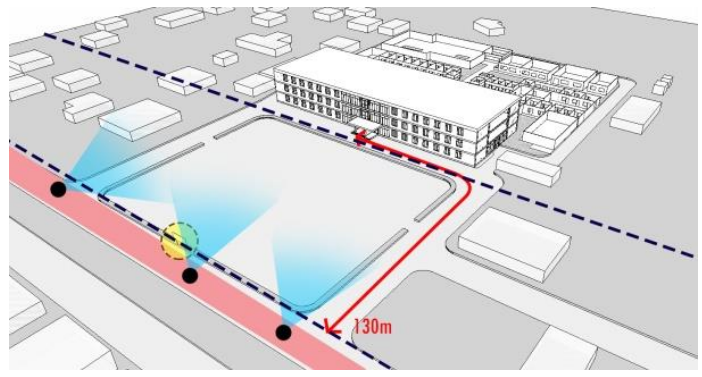

Gambar 12. Analisis jalur masuk tapak dan bangunan Panti Sasana Tresna Werdha Karya Bhakti Ria Pembangunan

Bangunan tidak kontras, massa dan jenis atap bangunan sama dengan sektiar. Sirkulasi lansia pada lingkungan Sasana Tresna Werdha Karya Bhakti Ria Pembangunan cukup sulit karena jaraknya cukup jauh dan tidak tersedia jalur pedestrian, namun sirkulasi lansia dalam bangunan sangat mudah karena tersedia lift, ramp pada bagian dropoff, serta ramp yang menghubungkan setiap lantai (Lihat gambar 16).

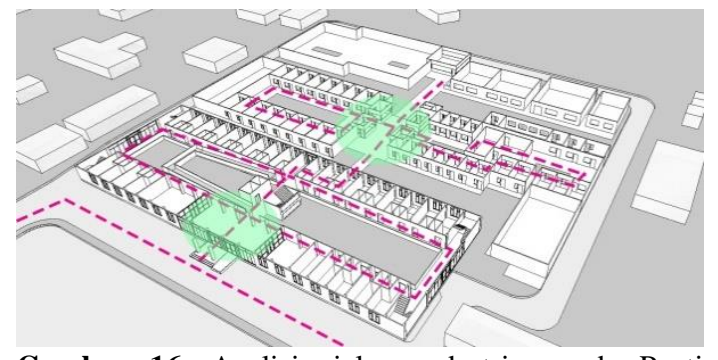

Gambar 16. Analisis jalur pedestrian pada Panti Sasana Tresna Werdha Karya Bhakti Ria Pembangunan

Perbedaan antara sirkulasi publik dan privat dapat dibedakan dari lebar sirkulasi (publik sangat lebar dan privat $1,2 \mathrm{~m}$ ). Sirkulasi dari kamar menuju fungsi atau fasilitas lainnya selalu melewati area publik terlebih dahulu (ruang tamu, ruang makan, dan pendopo). Area publik tersebut menghadap langsung ke taman tengah dan lapangan depan.

Sirkulasi menuju toilet cukup jauh $(45 \mathrm{~m})$ dan sirkulasi menuju tempat istirahat berupa ruang tamu sangat dekat $(8 \mathrm{~m})$. Pola sirkulasi tidak dinamis, karena bentuknya yang kaku yaitu kotak-kotak. Hanya terdapat 3 jenis pintu pada Sasana Tresna Werdha Karya Bhakti Ria Pembangunan, yaitu pintu double glass, single glass, dan pintu kayu.

Pada lingkungan Sasana Tresna Werdha Karya Bhakti Ria Pembangunan, tidak terdapat taman, yang ada hanya berupa area tanaman kecil. Taman berada pada bagian tengah setiap massa bangunan (taman pasif). Taman juga tidak berhubungan langsung dengan ruang komunal (padahal ruang komunal berupa semi outdoor). Yang terhubung langsung adalah koridor menuju ruang komunal.

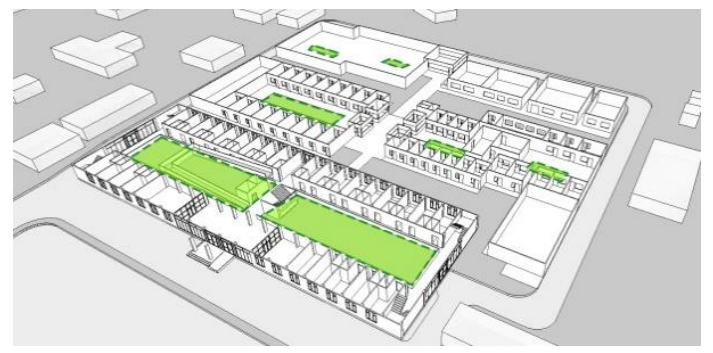

Gambar 13. Analisis taman rekreasi aktif dan pasif pada Panti Sasana Tresna Werdha Karya Bhakti Ria Pembangunan

\section{Bangunan}

Panti Sasana Tresna Werdha Karya Bhakti Ria Pembangunan terbagi ke dalam lima zonasi, dimana bangunan pertama terdapat pada 
bangunan utama yang ditemui dari bagian depan jalan terdiri dari 3 lantai, bangunan ini memiliki void di bagian tengah. Banguna di belakangnya merupakan bangunan lama yang sekarang digunakan sebagian untuk unit lansia yang lebih besar (nomor 2) dan untuk klinik kesehatan (nomor 3). Bangunan pendukung lainnya ditunjukan oleh nomor 4 sebagai tempat tidur yang disewakan jika ada keluarga yang menginap dan nomor 5 sebagai fasilitas pendukung yaitu musholla, kantin dan rumah dinas (Lihat gambar 18).

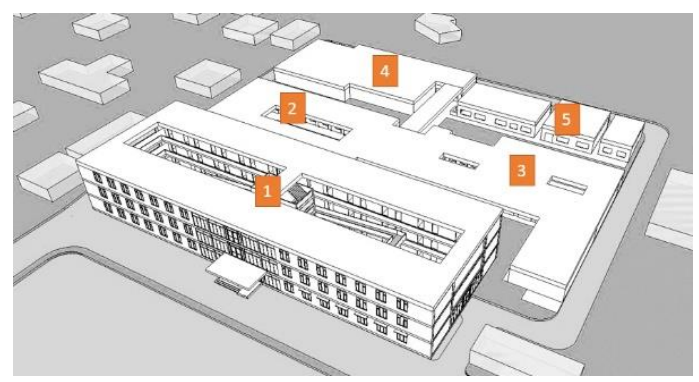

Gambar 14. Isometri bangunan Panti Sasana Tresna Werdha Karya Bhakti Ria Pembangunan

Fasilitas rekreasi hanya ditujukan untuk lansia dan tidak untuk umum. Fasilitas rekreasi ramah lansia, karena disediakan tempat duduk dan alat bantu, terdapat batu refleksi pada taman, dan penunjuk arah pada lantai. Taman olahraga tidak tersedia dalam Sasana Tresna Werdha Karya Bhakti Ria Pembangunan, yang ada berupa lapangan olahraga dan ruang fisioterapi pada bangunan.

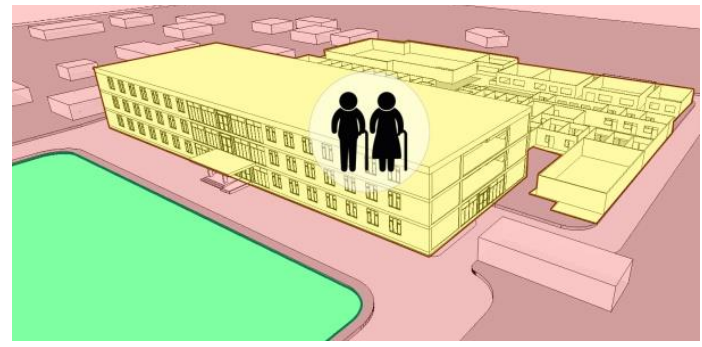

Gambar 15. Fasilitas Panti Sasana Tresna Werdha Karya Bhakti Ria Pembangunan

Sirkulasi mudah diidentifikasi lansia (publik dan privat) dapat terlihat dari lebar sirkulasi (Lihat gambar 20). Skema perjalanan kurang terasa, yang ada hanyalah dari bangunan baru menuju bangunan lama. Lansia dari unit kamarnya dapat langsung menuju taman tengah dengan mengakses ramp. Jumlah anak tangga sesuai dengan ketentuan, yaitu maksimal 10 anak tangga menuju bordes.

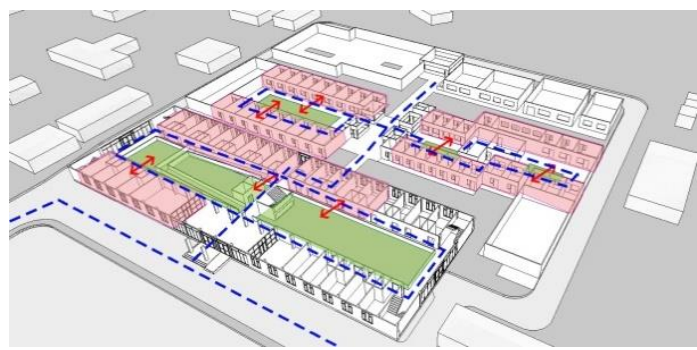

Gambar 16. Analisis sirkulasi dalam bangunan pada Panti Sasana Tresna Werdha Karya Bhakti Ria Pembangunan

Tidak tersedia taman kering, namun taman (taman basah) tersedia di setiap massa bangunan. Taman berhadapan langsung dengan unit hunian lansia, sirkulasi lansia tidak melewati taman.

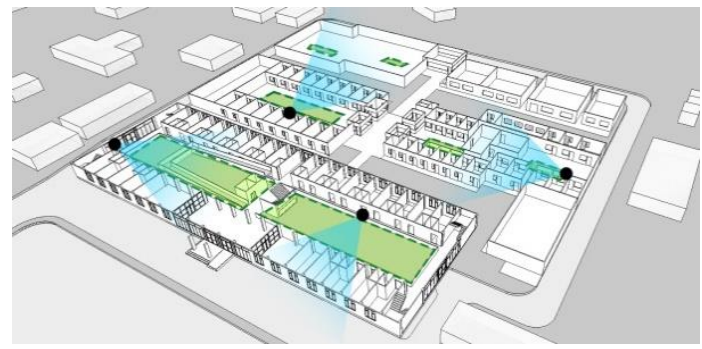

Gambar 17. Analisis balkon unti kamar pada Panti Sasana Tresna Werdha Karya Bhakti Ria Pembangunan

Cahaya yang masuk berupa cahaya tidak langsung yang dipantulkan oleh lantai dan difilter oleh kanopi jendela. Unit kamar tidak menyediakan balkon yang menghadap ke luar, namun menyediakan balkon pada bagian depan kamar yang bergabung dengan selasar dan menghadap ke taman tengah (Lihat gambar 22).

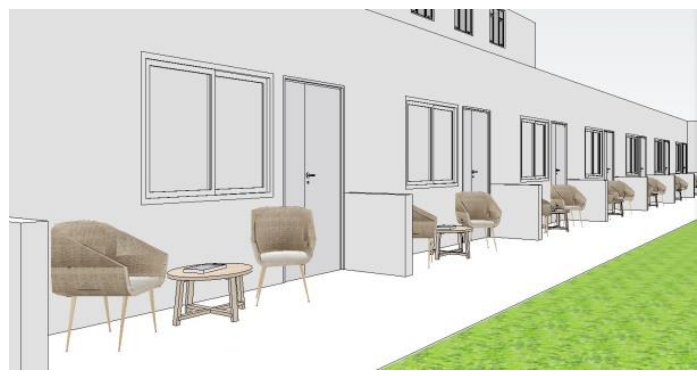

Gambar 18. Analisis balkon unti kamar pada Panti Sasana Tresna Werdha Karya Bhakti Ria Pembangunan

Bentuk massa bangunan tidak dinamis (kaku dan berbentuk kotak). Bukaan pada massa 
bangunan sudah cukup. Cahaya yang masuk ke bangunan berasal dari skylight, taman tengah, dinding yang dibiarkan terbuka, dan jendela kaca sehingga, terjadi cross ventilation.

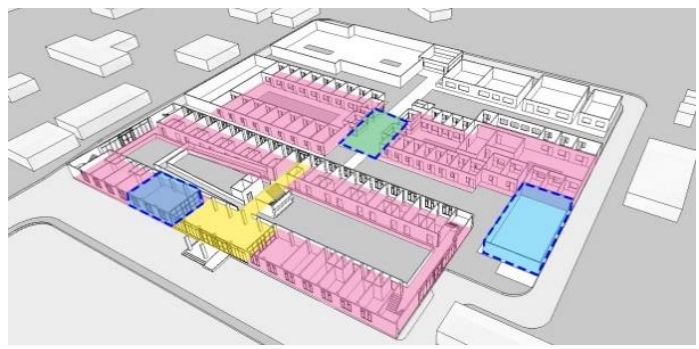

Gambar 19. Analisis zoning pada Panti Sasana Tresna Werdha Karya Bhakti Ria Pembangunan

Hierarki ruang juga telah sesuai, area publik pada bagian luar dan area privat pada bagian yang lebih dalam. Area publik (area komunal) yaitu pendopo merupakan pusat yang menghubungkan setiap massa bangunan (Lihat gambar 23).

Fasilitas yang disediakan untuk lingkungan sekitar yaitu mesh yang dapat disewa oleh para siswa. Sedangkan untuk lansia, fasilitas kebutuhan fisik dan psikologis telah disediakan dan dapat dilakukan di ruang kreasi, pendopo, dan aula. Ruang-ruang tersebut merupakan ruang fleksibel yang dapat dimanfaatkan sesuai kebutuhan.

Area servis berada pada bagian paling belakang dari bangunan, sehingga jauh terhadap unit kamar (Lihat gambar 24).

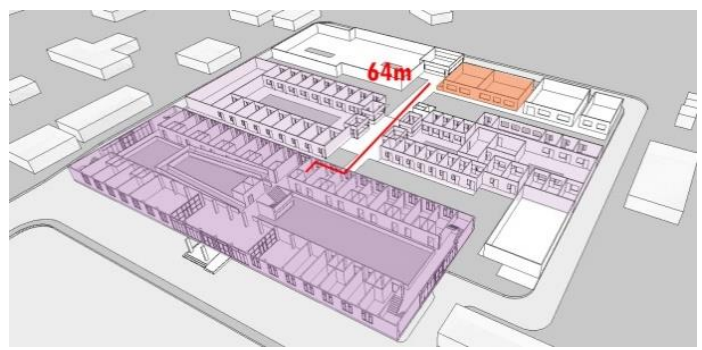

Gambar 20. Area servis pada Panti Sasana Tresna Werdha Karya Bhakti Ria Pembangunan

Area staff berbaur dengan unit hunian lansia, sehingga dapat memantau dan dekat dengan lansia. Jarak dari area staff menuju area servis juga cukup jauh yaitu 63m (Lihat gambar 25).

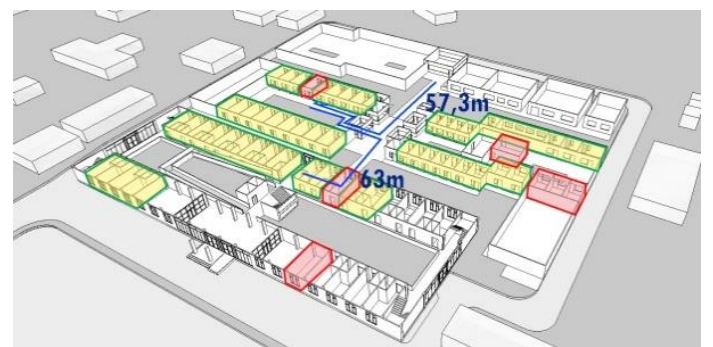

Gambar 25. Analisis staff pada Panti Sasana Tresna Werdha Karya Bhakti Ria Pembangunan

\section{Kesimpulan}

Jika dilihat dari analisis pada bagian lingkungan, Panti Werdha Wisma Mulia lebih ramah terhadap pergerakan lansia. Jarak antara bangunan dengan jalan hanya berkisar 6-10m jika dihitung menuju ke kamar membuat lansia dapat beraktivitas secara mandiri dan mendorong lansia untuk beraktivitas juga di luar bangunan. Taman rekreasi juga dekat dengan kamar sehingga pada jam berapa pun dapat digunakan karena adanya kecenderungan perbedaan penggunaan taman. Sirkulasi pedestrian pada bangunan Panti Werdha Wisma Mulia dapat dicapai dengan mudah karena bangunan yang tidak terlalu besar sehingga dapat ditempuh dengan waktu yang singkat.

Aspek lingkungan pada Sasana Tresna Werdha Karya Bhakti Ria Pembangunan jika dilihat dari jalur masuk tapak dan bangunan mempunyai jarak yang cukup jauh, melihat banyaknya pengunjung yang menggunakan transportasi online sehingga membuat lansia kurang dapat beraktivitas dengan mandiri, padahal kebergantungan harusnya dipertimbangkan agar lansia dapat beraktivitas sesuai dengan kemampuannya. Taman rekreasi pasif dan aktif pada Sasana Tresna Werdha Karya Bhakti Ria Pembangunan sangat besar dan banyak, namun karena terdiri dari 3 lantai maka taman hanya bisa di akses langsung oleh lansia di lantai 1 sedangkan lansia di lantai atas membutuhkan jarak tempuh lebih lama jika ingin beraktivitas di taman. Sirkulasi pedestrian bangunan ini baik, karena sampai ke lantai 3 disediakan ramp untuk aksesibilitas setiap lansia.

Pada aspek bangunan Panti Sasana Tresna Werdha Karya Bhakti Ria Pembangunan memiliki fasilitas pendukung untuk servis dan loading yang lengkap di bangunan yang terpisah. Unit Kamar juga terpisah dengan jelas sesuai dengan kebutuhan lansia di setiap lantainya. 
Sirkulasi dalam bangunan dapat diakses secara keseluruhan oleh lansia karena banyak nya rampi yang menghubungkan antar ruang dan juga antar lantai pada bangunan. Teras dan koridor di depan kamar juga digunakan untuk lansia bersantai dan berrekreasi sejenak.

Bangunan Panti Werdha Wisma Mulia memiliki fasilitas seadanya, servis dan loading tidak terdefinisi dengan jelas. Hanya terdapat ruang untuk pengurus di depan bagian bangunan yang menghadap jalan dan musholla dengan skala kecil. Namun, sirkulasi pada bangunan jelas membantu pergerakan lansia dengan mandiri, semua kamar menghadap ke ruang tengah menuju ruang serbaguna sehingga menjadikan tingkat sosial pada lansia tinggi.

Aspek rekreasi pada kedua studi kasus memang belum benar-benar terdefinisi untuk kegiatan rekreasi. Jika dilihat dari pola sirkulasi dan pengolahan ruang Sasana Tresna Werdha Karya Bhakti Ria Pembangunan karena memiliki ruang kosong yang banyak memungkinkan tempat rekreasi termasuk bersama keluarga dimana saja. Panti Werdha Wisma Mulia meski dengan ruang yang kecil tapi hierarki antar ruang jelas, ada ruang-ruang tengah kecil di setiap pertemuan ruang dan ruang yang paling besar untuk berrekreasi bersama di antara pertemuan bangunan. Jika melihat dari bentuk bangunan, kedua bangunan ini memiliki bentuk ruang yang masih mononton karena kurang dinamins, namun ruang-ruang tengah tetap disediakan pada kedua panti jompo tersebut.

Dapat disimpulkan kedua bangunan memiliki kelebihan masing-masing, namun jika dilihat dari kebutuhan lansia untuk berrekreasi dan beraktivitas secara mandiri maka Panti Werdha Wisma Mulia lebih unggul. Meski dengan lingukngan dan bangunan yang kecil namun panti jompo ini tepat guna. Sedangkan untuk Sasana Tresna Werdha Karya Bhakti Ria Pembangunan memang memiliki fasilitas lengkap namun dengan skala yang besar harusnya dapat diusulkan untuk mempunyai kantung-kantung ruang tersendiri sehingga kesan home dapat ditonjolkan dan lansia dapat beraktivitas secara mandiri.

\section{Referensi}

Badan Perencanaan Pembangunan Nasional. 2005. 'Tahun 2025, Angka Harapan Hidup Penduduk Indonesia 74,7 Tahun'. BAPPENAS. 2005. https://www.bappenas.go.id/id/berita-dansiaran-pers/berita/tahun-2025-angka-harapanhidup-penduduk-indonesia-737-tahun/.

Cowgill, Donald Oleh, and Lowell Don Holmes. 1972. Aging and Modernization. Sociology. United States: Appleton-Century-Crofts.

Devi, Evian. 2016. 'Pola Penataan Ruang Panti Jompo Berdasarkan Aktivitas Dan Perilaku Penghuninya'. ARTEKS: Jurnal Teknik Arsitektur 1 (1): 31-48. https://doi.org/10.30822/arteks.v1i1.24.

Harismi, Asni. 2019. 'Mengenal Konsep Angka Harapan Hidup Dan Faktor Yang Memengaruhinya'. SehatQ: Hidup Sehat. 2019. https://www.sehatq.com/artikel/angkaharapan-hidup-dan-faktor-yangmemengaruhinya.

Junaidi. 2007. 'Peranan Keluarga Dalam Pemeliharaan Penduduk Lanjut Usia'. Jambi. https://repository.unja.ac.id/111/1/lansia_juna idi2007.pdf.

Kuntjorowati, Elly. 2017. 'Nyaman Dan Tentram Di Rumah Pelayanan Lanjut Usia'. Jurnal PKS 16 (2): 209-22.

Laurens, Joyce Marcella. 2004. Arsitektur Dan Perilaku Manusia. Jakarta: Grasindo.

Martiani, Erna Rita, and Bambang Setioko. 2012. 'Graha Lansia Di Tangerang'. IMAJI - Jurnal Desain Arsitektur 1 (3): 371-80. https://ejournal3.undip.ac.id/index.php/imaji/ article/view/11702.

Michael, Yvonne L., Mandy K. Green, and Stephanie A. Farquhar. 2006. 'Neighborhood Design and Active Aging'. Health \& Place 12 (4): 734-40. https://doi.org/10.1016/j.healthplace.2005.08. 002 .

Murdiyanto, and Tri Gutomo. 2017. 'Peran Keluarga Dalam Mewujudkan Lanjut Usia Sejahtera'. Media Informasi Penelitian Kesejahteraan Sosial 41 (1): 1-10. https://ejournal.kemsos.go.id/index.php/medi ainformasi/article/view/1191/629.

P, Sabella Vicky, and Mariana Wibowo. 2014. 'Perancangan Interior Elderly Day Care Center Sebagai Pusat Aktivitas Manula Di Surabaya'. Intra 2 (2): 655-60. 
http://publication.petra.ac.id/index.php/desai n-interior/article/view/2262/2049.

Pemerintah Pusat. 2004. Peraturan Pemerintah (PP) Tentang Pelaksanaan Upaya Peningkatan Kesejahteraan Sosial Lanjut Usia. Indonesia. https://peraturan.bpk.go.id/Home/Details/661 88\#abstrak.

Putri, Suci Tuty, Lisna Anisa Fitriana, and Ayu Ningrum. 2015. 'Studi Komparatif: Kualitas Hidup Lansia Yang Tinggal Bersama Keluarga Dan Panti'. JURNAL PENDIDIKAN KEPERAWATAN INDONESIA 1 (1): 1. https://doi.org/10.17509/jpki.v1i1.1178.

Sajangbati, Pingkan L., Papia J. C. Franklin, and Leidy M. Rompas. 2015. 'Graha Komunitas Lansia (Pembaruan Konsep Perilaku Lansia)'. Jurnal Arsitektur DASENG 4 (1): 9-17. https://ejournal.unsrat.ac.id/index.php/daseng /article/view/6661/pdf.

Setiawan, Dewi. 2016. 'Faktor-Faktor Yang Mempengaruhi Kemampuan Perawatan Diri Pad Lansia Di Desa Windujaya Kecamatan Kedungbanteng Kabupaten Banyumas'. Muhammadiyah University. http://repository.ump.ac.id/753/.

Setiawan, Wawan, Rochmawati Tri P., Novi Nasar Intimetika, Qurota' Ayun, and Arni Levita Dwifina. 2014. 'Blok Rural Health Nursing'. Purwoketo https://www.academia.edu/9364924/perbedaa n_permasalahan_lansia_yang_tinggal_di_pan ti_jompo_dengan_lansia_yang_tinggal_deng an_keluarga.
Sitindaon, Fraciskus Rondang. 2009. 'Persepsi Lansia Penghuni Panti Wreda "Hanna" Yogyakarta Terhadap Panti Werdha "Hanna" Yogyakarta'. Sanatha Drarma University.

Siwalankerto, Jl. 2016. 'Perancangan Interior Panti Jompo Dengan Fasilitas Terapi Demensia Di Surabaya'. Intra 4 (1): 1-6. http://publication.petra.ac.id/index.php/desai n-interior/article/view/4028/3684.

Sugiharto, Adriana. 2017. 'Perancangan Bangunan Hunian Lansia Berdasarkan Aksesibilitas Penghuni Pada Lingkungan Dan Bangunan'. ARTEKS: Jurnal Teknik Arsitektur $1 \quad$ (2): $\quad 99-116$. https://doi.org/10.30822/arteks.v1i2.31.

Suryowati, Estu. 2018. 'Jumlah Lansia Di Indonesia Mencapai 22,4 Juta Jiwa Jadi Tantangan Program JKN'. JawaPos.Com, 2018.

Triwanti, Shinta Puji, Ishartono Ishartono, and Arie Surya Gutama. 2014. 'Peran Panti Sosial Tresna Werdha Dalam Upaya Meningkatkan Kesejahteraan Lansia'. Share: Social Work Journal 4 (2): 129-36. https://doi.org/10.24198/share.v4i2.13072. 
ARTEKS : Jurnal Teknik Arsitektur, Volume 5, Issue 2, August 2020 pISSN 2541-0598; eISSN 2541-1217 